\author{
半導体デバイス解析用局所プラズマ加工装置の開発(4) \\ プラズマ加工中の温度精密計測* \\ 岩瀬 千克*1 $\cdot$ 白山 裕也*1 $\cdot$ 横須賀俊太郎*1 $\cdot$ 樫村 健太 $* 1$ \\ 林 明宏 $* 1 \cdot$ 新堀俊一郎*1. 高橋 賢*2 堀江 智之 ${ }^{* 2}$ \\ 徳本 洋志 $* 2 \cdot$ 内藤 泰久 $* 2 \cdot$ 清水 哲夫 $* 2$
}

\title{
Development of Localized Plasma Etching System for Failure Analyses in Semiconductor Devices: (4) Precise Temperature Measured during Plasma Etching
}

\author{
Chikatsu IWASE*1, Yuya SHIRAYAMA*1, Shuntaro YOKOSUKA*1, Kenta KASHIMURA*1, \\ Akihiro HAYASHI*1, Shun'ichiro SHIMBORI*1, Satoshi TAKAHASHI*2, Tomoyuki HORIE*2, \\ Hiroshi TOKUMOTO*2, Yasuhisa NAITOH*2 and Tetsuo SHIMIZU*2
}

*1Sanyu Co.,Ltd., 457 Baba-cho, Hitachi Ota, Ibaraki 313-0004 Japan

*2National Institute of Advanced Industrial Science and Technology (AIST), Tsukuba Central 4, 1-1-1 Higashi, Tsukuba, Ibaraki 305-8562, Japan

(Received November 11, 2011, Accepted February 10, 2012)

\begin{abstract}
Temperature measurement of Si surfaces being etched by an inward plasma technique was performed with a sampling period of 0.1 s. A band edge thermometer was employed, which is based on the temperature dependence of the absorption edge of silicon. The temperature rise associated with the inward plasma etching was demonstrated to be smaller than that with an outward technique. Time dependence of the temperature and optical emission intensities from the plasma were measured simultaneously. As plasma was ignited and the discharge glowed, the temperature rose abruptly in the time domain within $3 \mathrm{~s}$, after which it approached a linear dependence. The transition in temperature change from an initial abrupt one to a linear manner coincided with the maxima of the optical emission intensity of $\mathrm{F}$ atoms as well as total emission intensity integrated between 200 and $1000 \mathrm{~nm}$. The magnitude of the initial temperature change linearly correlated with the intensity of the optical emission line by $\mathrm{F}$ atoms, i.e., the number of $\mathrm{F}$ radicals, while its correlation with the total intensity was obscured. It was therefore concluded that light absorption is not sufficient to explain the initial temperature change. Other effects including heat conduction of the etching gas to the surface and reaction heat associated with etching should be included.
\end{abstract}

\section{1. はじめに}

集積回路の大規模化 ${ }^{1)}$ に伴い, 故障解析の重要性が高まっ ている.これまでの故障解析に掞いてはパッケージを機械的 に研磨したのちに, 化学的なエッチングや集束イオンビーム (FIB) で絶緑膜を除去し, 配線が露出した試料を作製した のちに，電気的または表面分析的手法で故障個所と原因を特 定する ${ }^{2)}$. ところが機械研磨には研磨面の粗さ, 化学エッチ ングには液体の使用に伴う煩雑さ3,4), FIB には処理の遅さ と高いコストという問題があり, 素子をパッケージングの段 階から局所的に深堀りし, 配線を露出できる迅速で簡便な装 置の開発が求められてきた.

機械研磨, 化学エッチング, FIB 法の持つ問題点を解決 するために，局所プラズマ加工装置の開発を行ってきた5). この装置は試料近傍に接近させたキャピラリーを用いてエッ チングガスを吸引しながら, キャピラリー内部でプラズマを 発生させる. 発生したプラズマの一部分は上流側のキャピラ

* 平成23年11月 16 日 第52回真空に関する連合講演会で発表

*1 株式会社三友製作所（干313-0004 茨城県常陸太田市馬場町 457)

*2 独立行政法人産業技術総合研究所（下305-8562 茨城県つくば 市東 1-1-1 中央第 4)
リーと試料面との間に局所的に分布するために，局所的な試 料の加工が可能になるだけでなく, エッチングガスが常にキ ヤピラリーガスから吸引されるために, 加工残椬を大幅に減 少し, 内部の配線を損傷することなくエッチングすることが できる。

プラズマエッチング加工に拉いては, 試料とプラズマガス との熱交換や，エッチングに伴う反応熱による試料の温度上 昇は無視できない。半導体故障解析用の試料作製の場合に は, ウェハ全面を加工する場合とは異なり, 局所加工によっ て熱応力が $1 \mathrm{~mm}$ 以下の狭い領域に集中するため, デバイス プロセスとは異なる熱の影響が起き, 配線のはく離など素子 の損傷を招く可能性がある ${ }^{6)}$. 温度測定の手段として熱電対 を接触させる技術は確立しているものの, エッチング初期の 温度変化を熱電対で正確に追跡することは熱電対の熱伝導を 考えると難しいほか，プラズマ付近に熱電対を設置すること に伴う電気的ノイズの影響も温度測定を困難にしている. そこで, 本研究では分光学的温度計測法の一つであるバン ドエッジ温度計（BET）を用いた ${ }^{7,8)}$ 。この方法は $\mathrm{Si}$ をはじ めとする半導体の吸収端波長が温度によって敏感に変化する 性質を利用したものである. 半導体のバンドギャップは温度 が高いほど小さいため, 長波長から短波長に入射光を変化さ せたときの最初の吸光度の立ち上がりは, 半導体試料中の最 
高温度部分からの寄与が支配的であることを利用することに より，エッチング面の温度を選択的に測定することができる. BET による測定時間は分光装置のデータ処理時間によって 決まることから，現在のコンピュータの処理能力のもとでは 熱電対を用いた測定法に比べるとはるかに高い時間分解能で 温度測定することが可能となる. 本研究では $\mathrm{Si}$ を $\mathrm{CF}_{4}$ プラ ズマで加工しながら温度変化を BETにより測定した．まず 局所プラズマ加工装置における試料の温度上昇を，同一の局 所プラズマ加工装置に打ける噴出型と吸引型の配置で比較し た. 更にエッチング初期に打ける温度上昇を $\mathrm{Si}$ 面近傍にお けるプラズマからの発光スペクトル (OES) と同時に測定 し，エッチング初期の温度変化の機構について OESの時間 変化との関連から議論した.

\section{2. 実験}

Fig. 1 に装置の概略を示す．真空チャンバ（約1000 Pa） 内に試料を置き, $\mathrm{CF}_{4}$ ガスをチャンバ内に導入 $(1-40 \mathrm{sccm})$ した．試料にはキャピラリー（内径 $2 \mathrm{~mm} ）$ を距離 0.1-0.3 $\mathrm{mm}$ に接近させ，キャピラリーを通じてチャンバを排気し た。キャピラリーには外側と内側に一対の電極があり高周波 電力（13.56 MHz, 30-50 W) を印加してプラズマを発生さ せ，試料をエッチングした。チャンバの真空度やガスの流 量, キャピラリーと試料との距離などは外部のコンピュータ から制御した。プラズマからの紫外から可視領域にかけての 発光をモニタするため, キャピラリー先端と試料表面とを見 込む位置に空を設け, 光ファイバを置いてプラズマからの発 光を分光光度計 1 々と導いた. 吸引型から噴出型への配置 変更は，ポンプとガスの導入口の位置を置き換えて行った.

BET は市販品である Bandit（k-Space Associates, Inc., 米国）を用いた9). BET は $\mathrm{Si}$ のバンド吸収端である約 $1 \mu \mathrm{m}$ 付近の光を試料のエッチング面の反対側から照射するための 八ロゲン光源と, 試料を透過しエッチング面で散乱した光を エッチング面の反対側から集光する光学系と, 散乱光の分光 データから温度を計算するコンピュータ付きの分光光度計 2

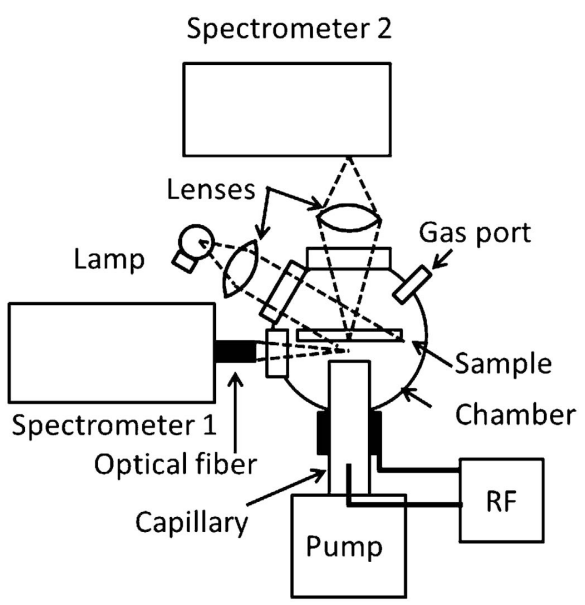

Fig. 1 A sketch of the experimental setup. The band edge thermometer consists of the Lamp, Lenses for focusing and the Spectrometer 2 for determining the band edge wavelength.
からなる．温度測定におけるエッチング開始時間は，エッチ ング装置への投入電力（RF 電源における FWD 值）の立ち 上がり時刻とし，温度は $0.1 \mathrm{~s}$ おきに，OESは $0.2 \mathrm{~s}$ おきに約 $300 \mathrm{~s}$ まで測定した。

序論で述べた通り, BET では半導体試料において最も温 度の高い箇所の吸収端を検出するため, 本研究で測定してい る温度は試料表面の温度である. それに対して，エッチング 面の反対側からの散乱の影響は測定結果の不確かさの要素と して寄与する10,11). 同様に, 入射光の迷光, プラズマから放 出される試料のバンド端より低エネルギー側の光などが検出 器に入ることが本測定に特有の不確かさ要因である.

同問題を解決するために，本研究では，試料表面抢よび裏 面からの正反射光や迷光, プラズマ発光が光検出器に届かな いように光学系の配置に留意した.

さらにBanditのコンピュータ付き分光光度計 2 の内部で は，分光データから温度を計算する際に，上述の不確かさ要 因を補正するためのデータ処理，たとえば数值微分により散 乱スペクトルの変曲点導出11)な゙が行われている.

\section{3. 結果と考察}

まず，吸引型配置が噴出型配置に比べて温度上昇の抑制と いう点で有利であることを確認した。配置以外の実験条件を 同一にしたうえで， $\mathrm{CF}_{4}$ プラズマによって $\mathrm{Si}$ 基板を 5 分間 エッチングした。それぞれの配置について，室温からの温度 上昇幅 $(\Delta \mathrm{T})$ とプラズマへの投入電力との関係を Fig. 2 に 示す．高温のプラズマガスを噴出する配置に対して加工領域 に常に新しいエッチングガスが供給される吸引型配置では, 同じ投入電力でも温度上昇は抑えられていた．室温の新しい エッチングガスの流入が試料の温度上昇を抑制する効果は, $\Delta \mathrm{T}$ とガス流量の関係を示した Fig. 3 に打いてさらに顕著 である. 噴出型ではガス流量の増加に伴って高温のプラズマ ガスによる基板の加熱が進行し， $\Delta \mathrm{T}$ が増加するのに対し て，吸引型では，ガス流量が増加すると基板表面に流入する 未反応のエッチングガスの流量が増加するため $\Delta \mathrm{T}$ のきさ は一定かやや減少する傾向を示す。

Figs. 2, 3 で示した吸引型配置による 5 分間のエッチング

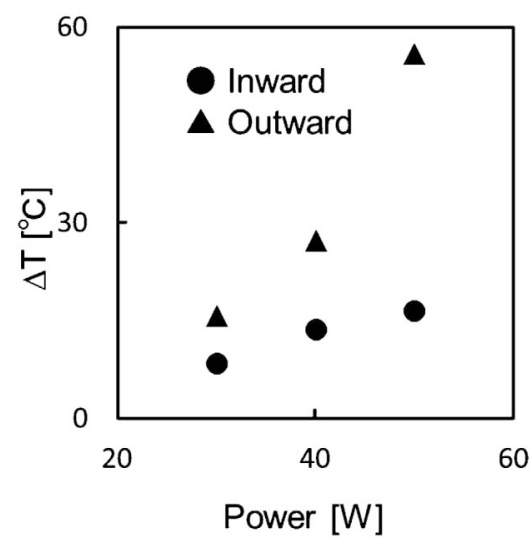

Fig. 2 Temperature changes on the Si wafer surface plotted as a function of the applied RF power for inward (circles) and outward (triangles) configurations measured after 5 miniute etching. 
において $\Delta \mathrm{T}$ と OES の時間変化をモニタした結果が Fig. 4 である。 $\Delta \mathrm{T}$ に重ねている直線は，100-300 s のデータを線 形近似して得られたものである. に急速に上昇してから徐々に一定の温度上昇へと近づく。一 方この間の OES の变化を200-1000 nm の積分強度, および $\mathrm{F}$ に打ける $3 \mathrm{p}{ }^{4} \mathrm{D}_{7 / 2} \rightarrow 3 \mathrm{~s}{ }^{4} \mathrm{P}_{5 / 2}$ の電子遷移に由来する発 光 ${ }^{12-14)}$ として知られている $686 \mathrm{~nm}$ の発光強度で見ると, エ ッチング開始と同時にこれらは最大值に達し, その後若干の 減少傾向を示しながらほぼ一定值となる. OESの時間変化 に若干の減少が観察される原因としてはキャピラリーの熱膨 張などによってプラズマの状態に微小な変動が起きているこ とが考えられる.

Fig. 4 の結果から, 基板の温度変化及び OESの主な変化

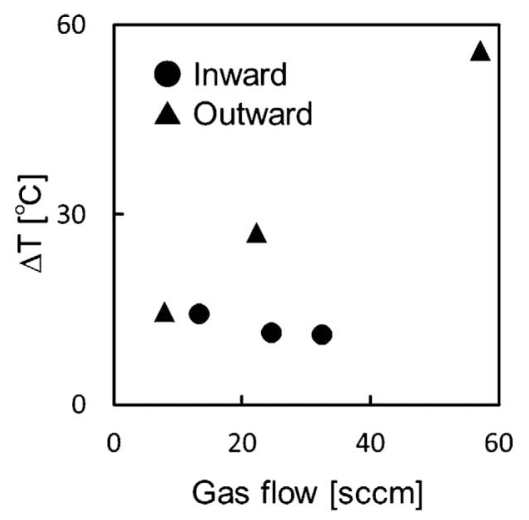

Fig. 3 Temperature changes on the $\mathrm{Si}$ wafer surface as a function of the mass flow of the etching gas for inward (circle) and outward (triangular) configurations after 5 miniute etching.
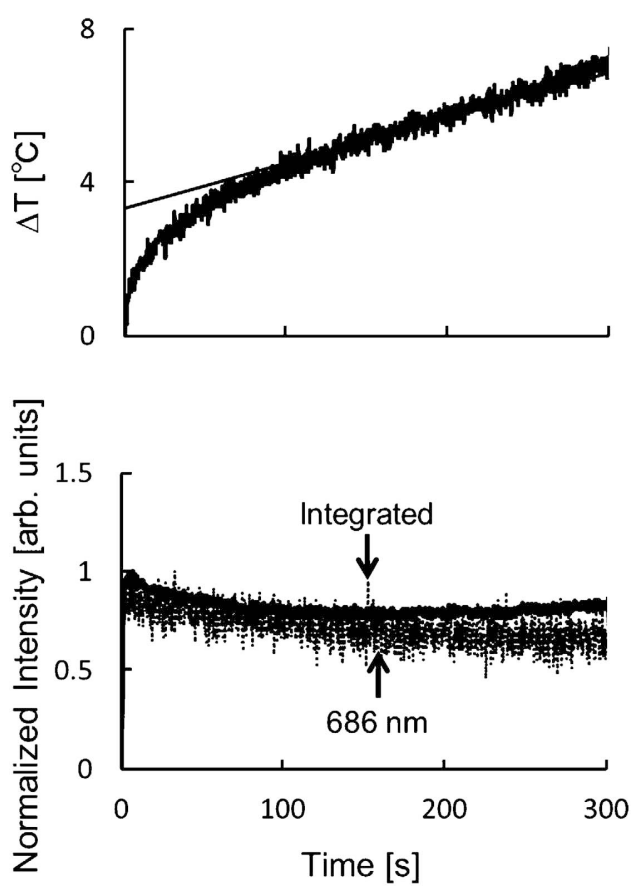

Fig. 4 Time dependence of the temperature change (upper trace), its linear fitting (straight line), and the total (200$1000 \mathrm{~nm}$ ) and $686 \mathrm{~nm}$ intensities of the optical emission (lower traces).
はエッチング開始後 $10 \mathrm{~s}$ 以内で終了することが予想され る.そこで, エッチング初期の変化を拡大して Fig. 5 に示 す. 温度変化の様子をより明確にするため $\Delta \mathrm{T}$ の対数を縦軸 にプロットする. $\Delta \mathrm{T}$ の初期の変化には Fig. 4 の $100 \mathrm{~s}$ まで にみられる温度上昇のほかに約 $3 \mathrm{~s}$ 以内に完了する急激な上 昇が存在することがわかる。なた，OESの結果においては Fig. 4 の結果に見られた初期の OES 信号強度の増加が約 $3 \mathrm{~s}$ 以内に完了して抽， $\Delta \mathrm{T}$ の $3 \mathrm{~s}$ 以内の急激な上昇は, プラ ズマ発光と相関があることがわかった.

エッチング初期の温度上昇と発光との関係をさらに調べる ために, 温度上昇から定常的な温度变化の影響を差し引くた め, Fig. 4 で示した近似直線を利用して $\Delta \mathrm{T}$ 軸との切片を初 期温度上昇と定義した. 初期温度上昇と, 発光強度がピーク に達している時刻 $3 \mathrm{~s}$ に測定した686 nm の発光線強度との 関係を Fig. 6 に示したところ, 両者は原点を通る比例関係 にあることが見出された. $686 \mathrm{~nm}$ の発光線は $\mathrm{F}$ 原子由来で

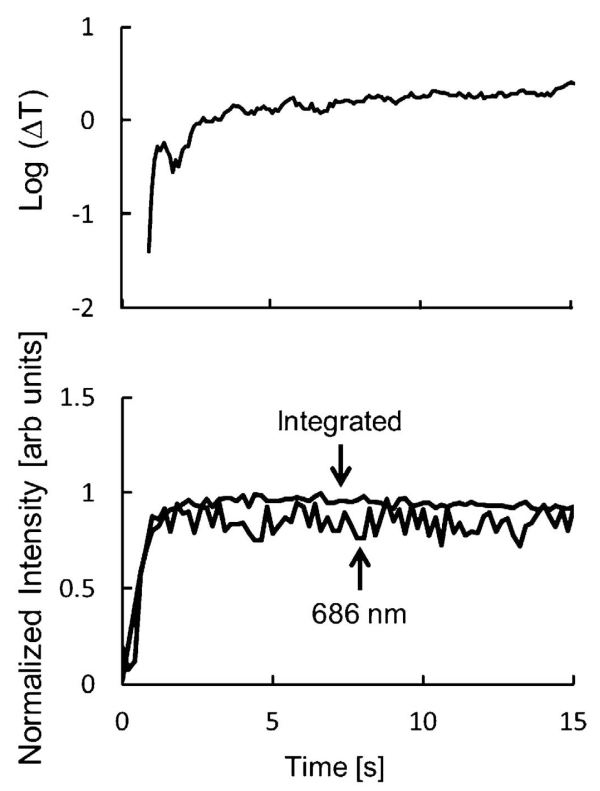

Fig. 5 Time dependence of the logarithm of the temperature change (upper trace) and the integrated $(200-1000 \mathrm{~nm})$ and $686 \mathrm{~nm}$ intensities of the optical emission (lower traces).

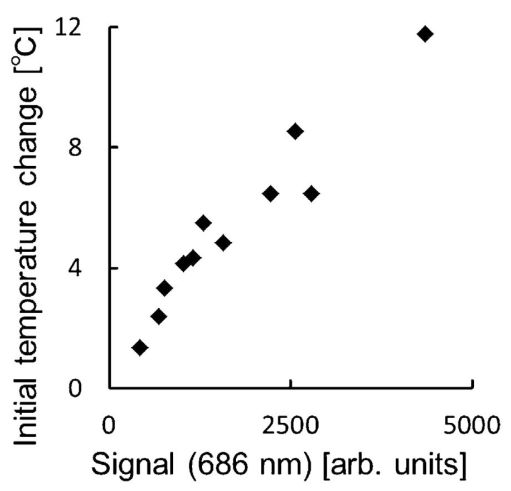

Fig. 6 Initial temperature changes plotted as a function of the light intensities at $686 \mathrm{~nm}$ emitted by $\mathrm{F}$ atoms. An initial temperature change is defined as the intercept of the linear equation deduced by the linear fitting of the temperature change data in the steady state region (see Fig. 4). 


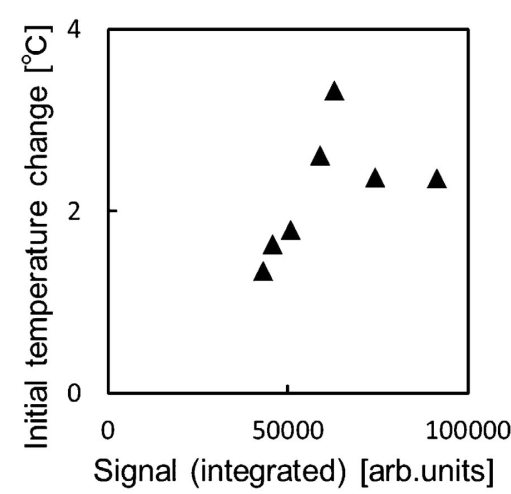

Fig. 7 Initial temperature changes plotted as a function of the total light intensities integrated between 200 and $1000 \mathrm{~nm}$.

あることが知られており，初期温度上昇はプラズマ中のラジ カルの濃度と関係があると結論できる。一方初期温度上昇と 積分強度との関係を図示すると Fig. 7 のようになり，両者 の相関は Fig. 6 と比較すると曖昧となる．Fig. 5 を見る限 り $3 \mathrm{~s}$ 以内の温度上昇の時間変化と積分強度, $686 \mathrm{~nm}$ の強 度の時間変化の傾向は一致していることから, 光の吸収の影 響は支配的であると考えられるが，Figs. 6，7 の結果を考慮 すると初期温度上昇は紫外打よび可視光の吸収だけでは完全 に説明できず，他の要素，たとえばプラズマガスと $\mathrm{Si}$ 表面 との熱交換，エッチングに伴う発熱などを加味する必要があ る.

Figs. 5-7 の結果からわかる範囲で基板の温度上昇の機構 について推定すると, エッチング開始後約 $3 \mathrm{~s}$ までは, RF 電力によりプラズマの発生が進行し, プラズマ内のラジカル 濃度が急速に上昇する。これに比例して $\mathrm{Si}$ 基板表面からの 光吸収が急激に進行するとともに，プラズマガスから基板表 面への熱伝導も進行する。これらの温度上昇はラジカルによ るエッチング速度を加速するため, 結果として反応熱による 温度上昇も加味される。これらの複合的な効果により, 基板 温度は急激に上昇する． $3 \mathrm{~s}$ を過ぎると，プラズマの状態は ほぼ安定し，Si の温度変化は基板内の熱拡散が支配的とな る.さらに $100 \mathrm{~s}$ から $300 \mathrm{~s}$ の間では，プラズマによる加熱 と熱拡散とが釣り合って温度上昇が定常となる。

\section{4. 結 論}

以上のように BET を用いた温度測定は局所プラズマ加工 装置を用いたエッチングに打いて, 試料の温度上昇に関する 種々の情報を与えることが示された．基板温度の時間変化は
エッチング初期 $3 \mathrm{~s}$ 以内は急激に上昇し, そののちは 1 次関 数的に緩慢な上昇を続けた。この時刻（3 s) はフッ素ラジ カルからの発光, およびプラズマ発光の積分強度が極大とな る時刻と一致し，初期温度上昇が輻射の吸収に起因すること が示唆された. 一方基板に抢ける初期温度上昇の大きさと, フッ素ラジカルからの発光, 拉よびプラズマ発光の積分強度 との比例関係を検討したところ, 初期温度上昇の大きさは,

フッ素ラジカルからの発光との比例関係がより明確であっ た．この比例関係の原因や，短時間プラズマエッチングされ た基板の加工深さや表面形状を調べることは今後の検討課題 であるが，温度変化の結果と比べることにより，本装置によ るエッチングの再現性やエッチング精度を高めるための基礎 的知見を得られるものと期待される.

\section{謝辞}

本開発は, 独立行政法人 科学技術振興機構による研究成 果展開事業【先端計測分析技術・機器開発プログラム】の一 環として行われました。ここに謝意を示します。

\section{〔文献〕}

1) International Roadmap Committee (Eds.): International Technology Roadmap for Semiconductors (ITRS), 2010 update, http:// www.itrs.net/links/2010itrs/home2010.htm

2) M. Fukui, Y. Mitsui, Y. Nara, F. Yano and T. Furukawa: Hitachi Rev., 55 (2006) 68.

3) M. Krishan, J. W. Nalaskowski and L. M. Cook: Chem. Rev., 110 (2010) 178.

4) Y. Ahn, J.-Y. Yoon, C.-W. Baek and Y.-K. Kim: Wear, 257 (2004) 785.

5) S. Shimbori, Y. Shirayama, T. Kawakami, S. Yokosuka, K. Kashimura, T. Wataya, T. Shimizu, Y. Naitoh and H. Tokumoto: J. Vac. Soc. Jpn., 53 (2010) 234.

6) R. P. S. Thakur, N. Chhabra and A. Ditali: Appl. Phys. Lett., 64 (1994) 3428.

7) S. R. Johnson, C. Lavoie, T. Tiedje and J. A. Mackenzie: J. Vac. Sci. Technol. B, 11 (1993) 1007.

8) T. P. Pearsall, S. R. Saban, J. Booth, B. T. Reard, Jr. and S. R. Johnson: Rev. Sci. Instrum., 66 (1995) 4977.

9) http://www.k-space.com/

10) R. N. Sacks, D. Barlett, C. A. Taylor II and J. Williams: J. Vac. Sci. Technol. B, 23 (2005) 1247.

11) S. R. Johnson and T. Tiedje: J. Crystal Growth, 175/176 (1997) 273.

12) NIST ASD Team (Eds.): NIST Atomic Spectra Database, ver. 4 (2009), http://physics.nist.gov/asd

13) M. Shimizu, K. Yasutake, H. Ohmi, A. Takeuchi, H. Kakiuchi, K. Yoshii and Y. Mori: Appl. Phys. B, 72 (2001) 227.

14) M. Shimizu, H. Ohmi, H. Kakuichi and K. Yasutake: J. Vac. Sci. Technol. A, 24 (2006) 2133. 